\title{
Reference values of hematological indices of infants, children, and adolescents in Port Harcourt, Nigeria
}

This article was published in the following Dove Press journal:

Pathology and Laboratory Medicine International

I July 2010

Number of times this article has been viewed

\section{Fl Buseri' \\ IJ Siaminabo ${ }^{2}$ \\ ZA Jeremiah'}

'Hematology and Blood Transfusion Sciences Unit, Department of Medical Laboratory Sciences, Niger Delta University, Wilberforce Island, Bayelsa State, Nigeria; ${ }^{2}$ Department of Hematology and Blood Transfusion, University of Port Harcourt Teaching Hospital, Port Harcourt, Rivers State, Nigeria
Correspondence: Zaccheaus Awortu Jeremiah

Department of Medical Laboratory Sciences, Niger Delta University, Wilberforce Island, Bayelsa State, Nigeria Tel +2348034045636

Email zacjerry@yahoo.com
Background: Lack of standard local reference values have been a problem facing hematological practice in Nigeria. Our aim was to establish reference hematological values from infancy to adolescence for future use in Nigeria.

Methods: A total of 1,021 apparently healthy Nigerian children aged 0-17 years were recruited for this cross-sectional descriptive study from the University of Port Harcourt Teaching Hospital, Port Harcourt, during preparatory exercises for immunization for Hepatitis B vaccine and from the Rivers State University of Science and Technology Day Care/Nursery, Primary, and International Demonstration Secondary School, Port Harcourt, during their standard medical examination prior to starting school. All hematological parameters were carried out using International Committee on Standardization in Hematology (ICSH) approved manual methods.

Results: We report a reference range study conducted in Port Harcourt infants (aged 1 day to less than 1 year), children ( 1 to less than 5 years, 5 to less than 9 years, 9 to 14 years), and adolescents (14 to 17 years old), establishing reference intervals for hematological parameters. Several differences were observed when compared to previously established values from Caucasians, most notably in hemoglobin, packed cell volume, platelets, total white blood cell count, and neutrophil values.

Conclusion: The values reported in this study can be used as local reference values for Port Harcourt infants, children, and adolescents.

Keywords: reference values, hematologic indices, infants, children, adolescents, Port Harcourt, Nigeria

Most reference values of hematologic indices currently used in Africa are derived from data collected for populations living in industrialized countries. ${ }^{1}$ The few small studies with African populations that have been reported indicate differences in normal values compared with those for populations in industrialized countries. ${ }^{2-6}$ Ethnic origin, genetics, gender, and environmental factors, especially altitude and pathogens, have been reported to affect the reference values of the hematological parameters, suggesting that the development of reference values for the African population is beneficial for quality health care. ${ }^{7-9}$ Genetic factors have been shown to contribute to all blood cell measures, accounting for between $61 \%-96 \%$ of variance..$^{3,7,10,11}$ Several studies have been carried out on children and adolescents of various ages, and significant differences have been reported in different populations, seasons, racial and ethnic groups, and gender subgroups. ${ }^{3,8-11}$ In most of these studies, the ethnic and sex differences are significant, with Caucasians' values being higher than those of Africans and AfroCaribbeans. ${ }^{3,12}$ It has therefore been stressed that each population must establish its own "normal reference values" for use in clinical assessments. ${ }^{9}$ 
Infancy, childhood, and adolescence are characterized by a dynamic period of growth and development in an individual. These different periods of life require special hematological consideration for several reasons; firstly that the chemical makeup of the circulating red blood cells as represented by their enzyme activities and fetal hemoglobin content in the first days and months is not identical with that in later life nor is the responsiveness of the hemopoietic system of the newborn and infant the same. Secondly, the hematopoietic system of the infant and the child, like all other systems at these age periods, undergoes development modification and growth, and moreover is peculiarly adapted to meet the requirements of these phases of life. ${ }^{13}$ Thirdly, hemopoietic (red) marrow occupies the entire capacity of the bones at birth through adolescence. In old age there is increased replacement with fatty marrow. ${ }^{9}$ This may affect the hematological parameters and result in different reference ranges for different age groups. ${ }^{14}$ Thus, knowledge of the normal blood values during this dynamic period of growth and development in an individual is a prerequisite for correct interpretation of a particular disease condition.

Though hematological reference values among apparently healthy adults and children have been established in many populations of Africans including Nigerians, there is a dearth of information regarding hematological normal reference values for infancy, childhood, and adolescence in Port Harcourt, Rivers State, Nigeria. This study, therefore, was aimed at establishing normal reference values of hematological parameters among Nigerian infants, children, and adolescents. Findings from this study will provide reference values for clinicians, particularly pediatric hematologists, to serve as a guide in deciding the health status during clinical assessments.

\section{Materials and methods Participants, setting, and design}

A total of 1,021 apparently healthy Nigerian children aged 0-17 years were recruited for this study from the University of Port Harcourt Teaching Hospital, Port Harcourt during preparatory exercises for immunization for Hepatitis B vaccine and from Rivers State University of Science and Technology Day Care and Nursery, Primary, and International Demonstration Secondary School, Port Harcourt during their standard medical examination prior to starting school. All the children were clinically examined by a trained medical officer and none of the study participants showed any sign of systemic illness; hence they were regarded as apparently healthy. The study was cross-sectional in nature.

\section{Blood sample collection and analyses}

Blood samples were collected by venipuncture using either the antecubital vein or the dorsal vein and dispensed into dipotassium EDTA anticoagulant bottles. Institutional ethical approval was received from the Department of Medical Laboratory Sciences, Rivers State University of Science and Technology, Port Harcourt. Thereafter, informed consents were obtained from their parents/guardians and teachers. Samples were collected between April 2008 and March 2009. All hematological parameters were carried out by manual methods as described by Bain et $\mathrm{al}^{3}$ on the same day of sample collection. Hemoglobin was determined by the cyanmethemoglobin method, packed cell volume by the microhematocrit method, total white cell count by Turks method, platelet count by the Brecher and Cronkite method using ammonium oxalate solution as the diluents, erythrocyte sedimentation rate (ESR) by the Westergreen method, and thin blood films were made by the push-wedge technique and stained with Leishman stain for the differential white cell count using the battlement technique. Adequate quality control measures were taken on each test procedure to ensure the reliability of the results.

\section{Statistical analyses}

Statistical analysis was performed using the computer software Statistical Package of Social Sciences (SPSS) for Windows version 14.0 (SPSS Inc., Chicago, USA) and Epi Info-version 6.04. Differences in proportions were analyzed using the Chi-square test or Fisher's exact test when appropriate. Results were considered to be statistically significant when the two-sided $P$ value was less than $0.05(P<0.05)$.

\section{Results}

A total of 1,021 apparently healthy Nigerian children constituted the study population. They were aged between 0.01 and 17.0 years. Males constituted 51.4\% (525/1021) while females constituted $48.6 \%$ (496/1021). Details of other results are as presented below. A total of $67.3 \%$ of the children were less than 5 years old and $32.7 \%$ were between 5 and 17 years of age, as shown in Table 1. Tables 2 and 3 show

Table I Frequency distribution of children studied according to age group

\begin{tabular}{ll}
\hline Age group & Number $(\%)$ \\
\hline$<1$ year & $368(36.0 \%)$ \\
$1-5$ years & $320(31.3 \%)$ \\
$5-9$ years & $170(16.7 \%)$ \\
$9-14$ years & $114(11.2 \%)$ \\
$>14$ years & $49(4.8 \%)$ \\
Total & $1021(100 \%)$ \\
\hline
\end{tabular}


Table 2 Reference hematologic values before the first year of life in term infants $(N=368)$

\begin{tabular}{|c|c|c|c|}
\hline Parameters & I-7 days $(n=87)$ & $8-14$ days $(n=98)$ & $\begin{array}{l}\text { I month- }<\text { I year } \\
(n=183)\end{array}$ \\
\hline $\mathrm{Hb}(\mathrm{g} / \mathrm{dl})$ mean $\pm \mathrm{SD}(95 \% \mathrm{Cl})$ & $16.5 \pm 1.6(13.5-18.0)$ & $14.7 \pm 3.0(13.0-16.0)$ & $12.7 \pm 0.09(\mid 2.5-14.0)$ \\
\hline $\mathrm{PCV}(\%)$ mean \pm SD $(95 \% \mathrm{Cl})$ & $45 \pm 8(40-53)$ & $44 \pm 9(38-5 I)$ & $37 \pm 2.4(33-4 I)$ \\
\hline ESR $(\mathrm{mm} / \mathrm{hr})$ mean $\pm \mathrm{SD}(95 \% \mathrm{Cl})$ & $2 \pm 1.5(0-6)$ & $5 \pm 2.8(0-10)$ & $7 \pm 2.8(I-15)$ \\
\hline Platelets $\left(\times 10^{9} / \mathrm{L}\right)$ mean $\pm \mathrm{SD}(95 \% \mathrm{Cl})$ & $270 \pm I I I(\mid 48-350)$ & $265 \pm 119(160-350)$ & $266 \pm 123(280-400)$ \\
\hline WBC $\left(\times 10^{9} / L\right)$ mean $\pm S D(95 \% \mathrm{Cl})$ & $9.7 \pm 4.1(8-18)$ & $8.9 \pm 4.3(7.8-16.0)$ & $7.8 \pm 4.5(4.0-10.0)$ \\
\hline \multicolumn{4}{|l|}{ WBC Differential count (WBC subsets)* } \\
\hline Neutrophil $\left(\times 10^{9} / \mathrm{L}\right)$ mean \pm SD $(95 \% \mathrm{Cl})$ & $5.0 \pm 2.0(3.0-9.0)$ & $4.0 \pm 2.0(2.0-7.0)$ & $4.0 \pm 2.0(0.9-6.0)$ \\
\hline Lymphocyte $\left(\times 10^{9} / \mathrm{L}\right)$ mean $\pm \mathrm{SD}(95 \% \mathrm{Cl})$ & $4.0 \pm 3.0(2.0-8.0)$ & $4.0 \pm 3.0(2.0-9.0)$ & $4.0 \pm 2.0(2.0-11)$ \\
\hline Monocyte $\left(\times 10^{9} / \mathrm{L}\right)$ mean $\pm \mathrm{SD}(95 \% \mathrm{Cl})$ & $0.5 \pm 0.03(0.1-0.5)$ & $0.5 \pm 0.03(0.1-0.7)$ & $0.5 \pm 0.02(0.1-0.5)$ \\
\hline Eosinophil $\left(\times 10^{9} / \mathrm{L}\right)$ mean $\pm \mathrm{SD}(95 \% \mathrm{Cl})$ & $0.4 \pm 0.02(0.02-0.80)$ & $0.4 \pm 0.02(0.02-0.80)$ & $0.4 \pm 0.02(0.02-0.90)$ \\
\hline Basophil $\left(\times 10^{9} / \mathrm{L}\right)$ mean \pm SD $(95 \% \mathrm{Cl})$ & - & - & - \\
\hline Band Forms mean $\pm S D(95 \% \mathrm{Cl})$ & $0.3 \pm 0.2(0.2-1.3)$ & $0.3 \pm 0.2(0.2-0.9)$ & $0.1 \pm 0.02(0.2-0.6)$ \\
\hline
\end{tabular}

Notes: *WBC subsets are expressed as absolute values.

the mean and the 95th percentile reference intervals for the total and differential white blood cell (WBC) counts, with significant differences among the age groups and a tendancy to decline significantly with advancing age until 14 years of age $(P<0.001)$. The normal differential leukocyte count did not vary with age as shown in Tables 2 and 3. Table 4 compares the mean and 95 th percentile reference ranges of the hematological parameters between 14 and 17 years according to gender. Significant changes were observed in the mean values of $\mathrm{Hb}, \mathrm{PCV}$, platelets, and $\operatorname{ESR}(P<0.01$ respectively) although none were in the white blood cells $(P>0.05)$.

\section{Discussion}

At birth the total hemoglobin $(\mathrm{Hb})$ level and packed cell volume $(\mathrm{PCV})$ in this study were shown to be consistently higher than at any other period of life. This is in agreement with earlier reports among Caucasians and African children. ${ }^{8,9}$ From birth to about 14 years of age there were no apparent gender difference in hemoglobin $(\mathrm{Hb})$ level and packed cell volume (PCV). However, statistically significant sex differences were observed from about 14 years in which the levels were higher in boys than in girls. This is in agreement with earlier reports among Saudi children ${ }^{8,15}$ and Ugandan children. ${ }^{16}$ In general, in several studies significant differences have been found in children at various ages and in adolescents in different populations, seasons, racial and ethnic groups, and gender subgroups. ${ }^{3,8,10,11}$ Genetic factors have been found to significantly contribute to all blood cell measures, accounting between $61 \%-96 \%$ of variance. ${ }^{7,17}$ In almost all studies, the ethnic and sex differences are significant, with Caucasians values being higher than those of Africans and Afro-Caribbeans. ${ }^{3,8,10-12,18,19}$ It has therefore been stressed that each population must establish its own "normal reference values" for use in clinical assessments. ${ }^{8}$

Table 3 Mean and 95th percentile reference ranges of the hematological parameters according to age group

\begin{tabular}{|c|c|c|c|c|}
\hline \multicolumn{5}{|l|}{ Age groups } \\
\hline Parameters & $\mathrm{I}-<5$ yrs $(\mathrm{n}=320)$ & $5-<9$ yrs $(n=170)$ & $9-<14$ yrs $(n=1 \mid 4)$ & $14-17$ yrs $(n=49)$ \\
\hline $\mathrm{Hb}(\mathrm{g} / \mathrm{dl})$ & $11.0 \pm 1.0(10.5-14.0)$ & $12.6 \pm 2.1(11.5-13.5)$ & $13.0 \pm 2.1(12.5-14.5)$ & $13.0 \pm 2.0(13.1-16.3)$ \\
\hline PCV (\%) & $34 \pm 3.0(31-44)$ & $37 \pm 5.0(33-44)$ & $38 \pm 5.0(35-45)$ & $39 \pm 6.0(38-48)$ \\
\hline WBC $\left(\times 10^{9} / L\right)$ & $8.9 \pm 6.0(6.5-13.2)$ & $7.4 \pm 3.1(5.3-11.0)$ & $6.5 \pm 3.1(4.4-10.7)$ & $7.4 \pm 4.0(3.0-10.0)$ \\
\hline PLAT $\left(\times 10^{9} / \mathrm{L}\right)$ & $261 \pm 98(117-365)$ & $255 \pm 88(120-376)$ & $263 \pm 85(130-405)$ & $282 \pm 119(100-430)$ \\
\hline $\operatorname{ESR}(\mathrm{mm} / \mathrm{hr})$ & $3 \pm 1.3(2-10)$ & $3 \pm 1.3(2-10)$ & $5 \pm 2.1(5-12)$ & $5 \pm 2.9(6-15)$ \\
\hline \multicolumn{5}{|l|}{ WBC (subsets)* } \\
\hline Neutrophil & $5.0 \pm 0.9(1.9-7.5)$ & $4.1 \pm 1.4(1.7-7.3)$ & $4.0 \pm 2.7(1.9-7.0)$ & $4.0 \pm 2.7(2.4-7.2)$ \\
\hline Lymphocyte & $4.0 \pm 1.9(3.1-9.0)$ & $4.0 \pm 1.7(1.2-6.0)$ & $3.0 \pm 1.0(1.1-3.2)$ & $3.0 \pm 1.0(1.1-3.2)$ \\
\hline Monocyte & $0.2 \pm 0.02(0.1-0.5)$ & $0.1 \pm 0.02(0.2-0.5)$ & $0.1 \pm 0.02(0.1-0.6)$ & $0.1 \pm 0.02(0.2-0.5)$ \\
\hline Eosinophil & $0.2 \pm 0.02(0.2-0.4)$ & $0.1 \pm 0.02(0.2-0.5)$ & $0.1 \pm 0.02(0.1-1.0)$ & $0.1 \pm 0.02(0.2-0.6)$ \\
\hline Basophil & $0.01 \pm 0.02(0.0-0.1)$ & $0.01 \pm 0.02(0.0-0.1)$ & Nil & Nil \\
\hline Immature WBCs & $0.3 \pm 0.02(0.2-0.4)$ & Nil & Nil & Nil \\
\hline
\end{tabular}

Notes: *WBC subsets are expressed as absolute values.

Abbreviation: yrs, years. 
Table 4 Comparison of mean and 95th percentile reference ranges of the hematological parameters of the children between 14 and 17 years according to gender $(n=49)$

\begin{tabular}{|c|c|c|c|}
\hline Parameters & Male $(n=22)$ & Female $(n=27)$ & $P$ values \\
\hline $\mathrm{Hb}(\mathrm{g} / \mathrm{dl})$ & $13.5 \pm 1.1(13.0-16.0)$ & $12.9 \pm 1.2(12.0-15.0)$ & $P<0.01$ \\
\hline PCV (\%) & $41.0 \pm 2.1(40.0-49.0)$ & $39.0 \pm 2.1(37.0-47.0)$ & $P<0.01$ \\
\hline WBC $\left(\times 10^{9} / \mathrm{L}\right)$ & $5.4 \pm 2.6(2.9-9.0)$ & $5.6 \pm 2.3(3.0-9.9)$ & $P>0.05$ \\
\hline PLAT $\left(\times 10^{9} / \mathrm{L}\right)$ & $269 \pm 98(98-427)$ & $285 \pm 111$ (100-443) & $P<0.01$ \\
\hline ESR $(\mathrm{mm} / \mathrm{hr})$ & $5 \pm 1.3(2-10)$ & $9 \pm 1.5(4-15)$ & $P<0.01$ \\
\hline \multicolumn{4}{|l|}{ WBC (subsets)* } \\
\hline Neutrophil & $4.0 \pm 2.6(1.9-7.0)$ & $4.0 \pm 2.7(2.4-7.2)$ & $P>0.05$ \\
\hline Lymphocyte & $3.0 \pm 1.0(1.1-3.2)$ & $4.0 \pm 1.7(1.2-6.0)$ & $P>0.05$ \\
\hline Monocyte & $0.2 \pm 0.02(0.2-0.6)$ & $0.2 \pm 0.02(0.2-0.6)$ & $P>0.05$ \\
\hline Eosinophil & $0.2 \pm 0.02(0.04-0.6)$ & $0.2 \pm 0.02(0.04-0.6)$ & $P>0.05$ \\
\hline Basophil & Nil & Nil & \\
\hline Immature WBCs & Nil & Nil & \\
\hline
\end{tabular}

A median white blood cell count of $8.3 \times 10^{9} / \mathrm{L}$ was obtained for the study population with a range of $2.9-18 \times 10^{9} / \mathrm{L}$. Miller ${ }^{13}$ indicated that at birth, the white cell count ranges between 9 and $30 \times 10^{9} / \mathrm{L}$, with the leukocytes predominantly made up of neutrophils. In this study, neutrophilic granulocytes predominate in the first 72 hours and were greater than that found in older children. Some neutrophils show a tendency to immaturity (shift to left), with a maximum of $10 \%$ band forms as well as occasional younger elements (myelocytes and metamyelocytes). This agrees with results gained by earlier researchers. ${ }^{9,20}$

The reference range obtained for the total white blood cell count among the children between the ages of 14 and 17 years establish the normal WBC count for Nigerian adolescents. The lower reference limit of $3.0 \times 10^{\%} / \mathrm{L}$ among Nigerians (Africans) is comparatively lower than those established in Europe ${ }^{9}$ and does not suggest leukopenia. The cutoff value for the lower limit of normal for Nigerian adults $\left(3.0 \times 10^{9} / \mathrm{L}\right)$ is caused by a genetically determined absolute neutropenia and therefore should not be overlooked in our clinical practice. Such lower limit of normal cut-off values for WBC has also been reported from other African countries. ${ }^{5,21}$ The total white blood cell count reference range of $4.0-11.0 \times 10^{9} / \mathrm{L}$ often quoted in hematology request forms in Nigeria refers to Caucasian values without regard to any particular age group. Leukocyte values of $2.5-11.0 \times 10^{9} / \mathrm{L}$ and $2.6-11.9 \times 10^{9} / \mathrm{L}$ for $6-10$ years and 11-15 year olds respectively has been previously reported by Ukaejiofo. ${ }^{22}$ El-Hazmi and Warsy ${ }^{8}$ reported a range in 15 year old children of $3.0-11.2 \times 10^{9} / \mathrm{L}$ in females and $3.8-12.1 \times 10^{9} / \mathrm{L}$ in males, while our range in the 14 to 17 year old children was $3.0-9.9 \times 10^{9} / \mathrm{L}$ in females and $2.9-9.0 \times 10^{9} / \mathrm{L}$ in males.
The absolute number of neutrophils predominates in the first few days after birth without gender differences and then falls during the succeeding days. Immature forms, including band forms as well as occasional younger elements (myelocytes and metamyelocytes) were seen in the first few days of life. It is reported that the level after the first 72 hours is very stable for an individual infant. ${ }^{20}$ As the neutrophil number decreases, the lymphocyte becomes the predominant cell type in childhood up to the fifth year of life, without sex difference. ${ }^{9}$ In this study we did not find any gender differences both for the total white blood cell count and the leukocyte subsets, probably due to absence of significant hormonal influences in these age range. The general absence of gender differences for WBC counts is in agreement with results of previous reports. ${ }^{11,23,24}$ The children aged between 14 and 17 showed significant sex differences with the girls having higher values than the boys for neutrophil and lymphocyte counts. These differences could be due to activities of sex hormones which are effective in this age group. This is in agreement with the findings of Hsieh et al. ${ }^{25}$ Monocyte numbers range from 0.1 to $0.6 \times 10^{9} / \mathrm{L}$ and do not vary during infancy and childhood. An absolute eosinophil count of $0.8 \times 10^{9} / \mathrm{L}$ was maintained in the infants less than one year which then declines to $0.5 \times 10^{9} / \mathrm{L}$ in the children less than 9 years with a slight increase among the children between 9 and less than 14 years and again decrease to $0.5 \times 10^{9} / \mathrm{L}$ in the 14 and 17 years age group. Limited evidence was gained in this study to support the concept that Africans have lower or higher monocyte and eosinophil counts than Caucasians. Any higher eosinophil count observed in Africans may be due to an inciting cause, particularly parasitic infection, rather than an ethnic difference. 
The ESR was lower in the children less than 1 year of age compared to those who were older and this tends to increase with age. Lewis ${ }^{9}$ also noted that in newborns, the ESR is usually low. In this study a gender difference was noticed in the children aged 14 years and above, with the girls having higher values than the boys. This is contrary to the findings of Lewis, ${ }^{9}$ who reported that the ESR is the same in childhood and adolescence with no sex difference. The 95th percentile reference ranges of the ESR of the children within 14 and 17 years of age were $2.0-10.0 \mathrm{~mm} / \mathrm{hr}$ for males and $4.0-15.0 \mathrm{~mm} / \mathrm{hr}$ for females. This is not in agreement with the normal range of $3-5 \mathrm{~mm} / \mathrm{hr}$ for males and $4-7 \mathrm{~mm} / \mathrm{hr}$ for females reported by Inwood et al. ${ }^{26}$

The 95th percentile reference ranges for the platelet counts varies at the different age periods, showing a progressive increase from the children less than 1 year of age to those aged 17 years. In each age group, the lower limit of normal was observed to be consistently lower than the reference values reported among the Caucasians. ${ }^{9}$ Moreover, the mean platelet counts for both the girls and boys between the ages of 14 and 17 years $285 \pm 111$ (range, $100-443 \times 10^{9} / \mathrm{L}$ ) and $269 \pm 98$ (range, $98-427 \times 10^{9} / \mathrm{L}$ ), respectively, indicated lower values for the lower limits while the upper limits are similar to those reported by Lewis among Caucasians. ${ }^{9}$ The differences are sufficient to be of practical importance in interpreting counts around the lower end of the reference range. For example, the Caucasian value of $150 \times 10^{9} / \mathrm{L}$ cannot be applied to interpret thrombocytopenia in this our Nigerian environment. In this study we also observed sex differences in platelet count among the children between 14 and 17 years with the girls having higher values than the boys. This is in agreement with the report of Taylor et al. ${ }^{11}$ Bao et $\mathrm{al}^{12}$ reported that compared with the females, males between 12 and 17 years have a mean $14 \times 10^{9} / \mathrm{L}$ lower platelet count. The low platelet count and the gender difference in platelet counts in this study population are similar to those observed in other studies within African populations. ${ }^{3,5,16}$ The cause of the lower platelet counts among populations of African origin is unknown. Environmental and genetic factors may play a role. ${ }^{3,5,16}$ Morphological examination of the platelets of the infants shows greater variation in size and shape than those of older children. This observation is in agreement with the findings of Lewis. ${ }^{9}$ The ranges reported in this study can be used as normal reference ranges for children in this environment.

\section{Conclusion}

From results gained in this study, it can be concluded that hematological values differ by age, sex, and race. These differences should be considered when defining normal and 'abnormal' hematological values. Notably, our $\mathrm{Hb}, \mathrm{PCV}$, platelet, WBC, and neutrophil values were lower than those reported for Caucasians.

\section{Disclosure}

The authors report no conflicts of interest in this work.

\section{References}

1. Wintrobe MM, Lee GR. Wintrobe's Clinical Hematology, 11th ed. Williams and Wilkins Co., Baltimore. 2006.

2. Badenhorst CJ, Fourie J, Steyn K, et al. The haematological profile of urban black Africans aged 15-64 years in the Cape Peninsula. East Afr Med J. 1995;72:19-24.

3. Bain BJ. Ethnic and sex differences in the total and differential white cell count and platelet count. J Clin Pathol. 1996;49:664-666.

4. Coetzee MJ, Badenhorst PN, de Wet JI, Joubert G. Haematological condition of the San (Bushmen) relocated from Namibia to South Africa. S Afr Med J. 1994;84:416-420.

5. Tsegaye AT, Messele T, Tilahun E, et al. Immunohematological reference ranges for adult Ethiopians. Clin Diagn Lab Immunol. 1999;6:410-414.

6. Tugume SB, Piwowar EM, Lutalo TP, et al. Hematological reference ranges among healthy Ugandans. Clin Diagn Lab Immunol. 1995;2:233-235.

7. Evans DM, Frazer IH, Martin NG. Genetic and environmental causes of variation in basal levels of blood cells. Twin Research. 1999;24:250-257.

8. El-Hazmi MAF, Warsy AS. Normal reference values for haematological parameters, red cell indices, $\mathrm{HbA}_{2}$ and $\mathrm{HbF}$ from early childhood through adolescence in Saudis. Ann Saudi Med. 2001;21: $165-169$.

9. Lewis SM. Reference ranges and normal values. In: Lewis SM, Bain BJ, and Bates I, Editors. Dacie and Lewis Practical Hematology. 10th ed. Churchill Livingstone, Philadelphia: 2006. p. 11-24.

10. Akdag R, Energin VM, Kalayei AG, Karakelleoglv V. Reference limits for routine haematological measurements in 7-14 year old children living in an intermediate altitude. Scand J of Clin Lab Invest. 1996;56:103-109.

11. Taylor MR, Holland CV, Spencer R, Jackson JF, O'Connor GI, O'Donnell JR. Haematological reference ranges for school children. Clin Lab Haematol. 1997;19:1-15.

12. Bao W, Dalferes ER Jr, Srinivasan SR, Webber LS, Berenson GS. Normative distribution of complete blood count from early childhood through adolescence in the Bogalusa Heart Study. Preventive Med. 1993;22:825-837.

13. Miller DR. Normal blood values from birth through adolescence. In: Miller DR, Baehner RL, Editors. Blood diseases of infancy and childhood. 7th ed. Mosby, St Louis: 1995. p. 30-53.

14. Odunukwe NN, Imonugo IO, Akanmu AS, et al. Ferritin and haematological values in healthy elderly Nigerians. Turkish J Haematol. 2004;21:71-77.

15. Bain BJ, Lewis SM, Bates I. Basic haematological technigues. In: Lewis SM, Bain BJ, Bates I, Editors. Dacie and Lewis Practical Hematology. 10th ed. Churchill Livingstone, Philadelphia: 2006. p. $25-57$.

16. Lugada ES, Mermin J, Kaharuza F, et al. Population-based haematologic and immunologic reference values for a healthy Ugandan population. Clin Diag Lab Immunol 2004;11:29-34.

17. Dal Colletto GM, Fulker DW, Barretto OC, Kolya M. Genetic and environmental effects on blood cells. Acta Genet Med Gemellol (Roma). 1993;42:245-252.

18. Saxena S, Wong EI. Heterogeneity of common haematologic parameters among racial, ethnic and gender subgroup. Arch Pathol Lab Med. 1990;14:715-719. 
19. Nduka N, Aneka C, Maxwell-Owhochukwu S. Comparison of some haematological indices of Africans and Caucasians resident in the same Nigerian environment. Haematologica. 1988;21:57-63.

20. Segel GB, Palis J. Hematology of the newborn. In: Lichtman MA, Beutler E, Kipps TJ, Seligsohn U, Kaushansky K, Prchal JT, Editors. William's Hematology. 7th ed. McGraw-Hill Medical, New York: 2006. p. 81-99.

21. Sahr F, Hazra PK, Grillo TA. White blood cell count in healthy Sierra Leoneans. West Afr J Med. 1995;14:105-107.

22. Ukaejiofo EO. Haematological values among Nigerian children aged 6-10 years. J Med Lab Sci. 1996;5:111-113.
23. Ukaejiofo EO. Blood counts in Nigerian older children aged 11-15 years. J Med Lab Sci. 1996;5:114-116.

24. Ghafouri HM, Al-Fares AM, Islam SI, Ahmed AO, Jan MY. Haematological reference values assessed from birth to adolescence in Saudi subjects in the area of Jeddah. Saudi Med J. 1987;8:575-582.

25. Hsieh MM, Everhart JE, Byrd-Holt DD, Tisdale JF, Rodgers GP. Prevalence of neutropenia in the U.S. population: Age, sex, smoking status, and ethnic differences. Ann Intern Med. 2007;146:486-492.

26. Inwood MJ, Thomson S, Bryant NJ. Immunohematology and hematology. In: Raphael SS, Editor, Lynch's medical Laboratory technology. 4th ed. W.B: Saunders company; 1983; p. 615-754.

\section{Publish your work in this journal}

Pathology and Laboratory Medicine International is a peer-reviewed, open access journal focusing on innovative basic research and translational research related to pathology or human disease. The journal includes original research, updates, case reports, reviews and commentaries on current controversies. The Academic Sponsor of this journal is the Chinese American Pathology Association (CAPA). The manuscript management system is completely online and includes a very quick and fair peer-review system. Visit http://www.dovepress.com/testimonials.php to read real quotes from published authors.

Submit your manuscript here: http://www.dovepress.com/pathology-and-laboratory-medicine-international-journal 